\title{
Analysis of glucose-6-phosphate dehydrogenase in anterior subcapsular and mixed cataractous lenses
}

\author{
M Balaji, K Sasikala, G Sundararajulu, T Ravindran, M Latheef Sathar
}

\begin{abstract}
The study was undertaken to determine the different concentrations of glucose-6phosphate dehydrogenase (G-6-PD) in anterior subcapsular and mixed cataractous lenses. In both types of cataractous lenses an increased concentration of G-6-PD was observed in 41-50 year age groups and a lower concentration of G-6-PD was noted in 61 year and above age groups. Cataractous lenses of females have a higher content of G-6-PD than males. In anterior subcapsular cataractous lenses, a lower concentration of G-6-PD was noted than in mixed lenses. (Br f Ophthalmol 1995; 79: 1124-1125)
\end{abstract}

Deficiency of glucose-6-phosphate dehydrogenase (G-6-PD) in cataract lenses has been reported by many researchers. ${ }^{1-4}$ It is transmitted as an X linked character; in heterozygous women a wide range of G-6-PD deficiency 4 has been noted. There are few reports on G-6-PD deficiency in the lenses of human, mouse, ox, and rabbit. ${ }^{5-7}$

Owing to the paucity of information available in the anterior subcapsular and mixed human lenses in Tamil Nadu, India, we analysed the G-6-PD activity of lenses in patients with anterior subcapsular and mixed cataract, to study the levels of enzyme deficiency.

\section{Material and methods}

This investigation was carried out on 300 patients. Cataractous lenses were collected from various eye hospitals of Coimbatore between January and May, 1994 and were categorised as anterior subcapsular and mixed cataracts as stipulated by the Oxford classification. ${ }^{8}$ The age and sex of the patients were recorded. For controls, normal lenses of both sexes were obtained from an eye bank located in Coimbatore.

The lenses were collected in glass containers, washed with double distilled water, oven dried, and weighed separately. Glucose-6phosphate dehydrogenase levels were assessed according to Zinkham's method, ${ }^{9}$ and the data were analysed statistically by using Student's $t$ test for significance.

\section{Results and discussion}

Glucose-6-phosphate dehydrogenase content in lenses of males and females decreased as the age group of the patients increased. Lenses of females have larger amounts of G-6-PD than males in both anterior subcapsular and mixed
Table 1 Glucose-6-phosphate dehydrogenase content in lenses with mixed cataract

\begin{tabular}{|c|c|c|}
\hline & $\begin{array}{l}\text { No of } \\
\text { subjects } \\
\text { analysed }\end{array}$ & $\begin{array}{l}\text { Glucose-6-phosphate dehydrogenase } \\
\text { ( } \mu \text { mol NADP reduced } \\
\left.100 \mathrm{mg} \text { protein } h^{-1}\right) \\
\text { Mean (SD) }\end{array}$ \\
\hline \multicolumn{3}{|l|}{ Males: } \\
\hline \multicolumn{3}{|l|}{ Controls } \\
\hline Group I & 10 & $20 \cdot 2(2 \cdot 11)$ \\
\hline Group II & 10 & $23 \cdot 1(2 \cdot 22)$ \\
\hline Group III & 10 & $30 \cdot 4(2 \cdot 80)$ \\
\hline \multicolumn{3}{|l|}{ Experimentals } \\
\hline Group I & 25 & $17 \cdot 3(1 \cdot 78)^{\star}$ \\
\hline Group II & 25 & $14.7(1.68)^{\star}$ \\
\hline Group III & 25 & $13.8(1.66)^{\star}$ \\
\hline Females: & & \\
\hline \multicolumn{3}{|l|}{ Controls } \\
\hline Group I & 10 & $21.0(3.06)$ \\
\hline Group II & 10 & $25.4(3.48)$ \\
\hline Group III & 10 & $32.6(3.67)$ \\
\hline \multicolumn{3}{|l|}{ Experimentals } \\
\hline Group I & 25 & $18.0(1.27)^{\star}$ \\
\hline Group II & 25 & $16.8(1.20)^{\star}$ \\
\hline Group III & 25 & $14.8(1.70)^{\star}$ \\
\hline
\end{tabular}

Group I: 41-50 years; Group II: 51-60 years; Group III: $61-70$ years. ${ }^{\star}$ Values significant at $5 \%$ level.

cataractous lenses (Tables 1 and 2). The age group and the G-6-PD content were found to be inversely proportional to each other in both anterior subcapsular and mixed cataractous lenses. When compared with their respective controls, a decreased content of G-6-PD was observed. The lenses of mixed cataract showed an increase in the content of G-6-PD compared with anterior subcapsular lenses.

The results of the present study showed that both the anterior subcapsular and mixed cataract lenses of females have more G-6-PD than those of males.

In the normal lens, G-6-PD is involved in a series of activities, as yet only partially known, that are indispensable for the growth of its cells

Table 2 Glucose-6-phosphate dehydrogenase content in lenses with anterior subcapsular cataract

\begin{tabular}{|c|c|c|}
\hline & $\begin{array}{l}\text { No of } \\
\text { subjects } \\
\text { analysed }\end{array}$ & $\begin{array}{l}\text { Glucose-6-phosphate dehydrogenase } \\
\text { ( } \mu \text { mol NADP reduced/ } \\
\left.100 \mathrm{mg} \text { protein } h^{-1}\right) \\
\text { Mean (SD) }\end{array}$ \\
\hline \multicolumn{3}{|l|}{ Males: } \\
\hline \multicolumn{3}{|l|}{ Controls } \\
\hline Group I & 10 & $20 \cdot 2(2 \cdot 11)$ \\
\hline Group II & 10 & $23 \cdot 1(2 \cdot 22)$ \\
\hline Group III & 10 & $30.4(2 \cdot 80)$ \\
\hline \multicolumn{3}{|l|}{ Experimentals } \\
\hline Group I & 25 & $15.6(2.25)^{\star}$ \\
\hline Group II & 25 & $13.5(1.47)^{\star}$ \\
\hline Group III & 25 & $12.0(1.82)^{\star}$ \\
\hline Females: & & \\
\hline \multicolumn{3}{|l|}{ Controls } \\
\hline Group I & 10 & $21 \cdot 0(3.06)$ \\
\hline Group II & 10 & $25.4(3.48)$ \\
\hline Group III & 10 & $32.6(3.67)$ \\
\hline \multicolumn{3}{|l|}{ Experimentals } \\
\hline Group I & 25 & $17.0(1.80)^{\star}$ \\
\hline Group II & 25 & $15 \cdot 2(1 \cdot 28)^{\star}$ \\
\hline Group III & 25 & $13 \cdot 2(1 \cdot 14)^{\star}$ \\
\hline
\end{tabular}

Group I: 41-50 years; Group II: 51-60 years; Group III: $61-70$ years. *Values significant at $5 \%$ level. 
and for the maintenance of transparency. ${ }^{10} \mathrm{It}$ has been demonstrated that a person with genetically determined deficiency of G-6-PD may be more susceptible to cataract formation. ${ }^{10}$

Glucose-6-phosphate dehydrogenase is an enzyme of the hexose monophosphate shunt which supplies $\mathrm{NADPH}_{2}$. This $\mathrm{NADPH}_{2}$ is utilised by glutathione reductase for the generation of reduced glutathione. ${ }^{11}$

In conclusion, it was observed that the decreased content of G-6-PD in both male and female lenses, when compared with controls, could, owing to the deficiency of G-6-PD, affect the pentose pathways resulting in reduced glutathione activity, making the lens more prone to oxidative damage. Possibly, lipid peroxidation might be responsible for the loss of solubility and stability of the lens proteins. 51012

The authors are grateful to various eye hospitals, who supplied necessary materials during the course of study. $M$ Balaji is grateful to the Council of Scientific and Industrial Research (CSIR), New Delhi, for the award of senior research fellowship.

1 Panich V, Sungnate T. Characterization of glucose-6phosphate dehydrogenase in Thailand. The occurrence of variants among 50 glucose-6-phosphate dehydro- genase deficient patients. Thai Humangenetik 1973: 39-46.

2 Panich V, Na-Nokorn S. Glucose-6-phosphate dehydrogenase deficiency in mixed cataracts. Hum Genet 1980; 55: $123-4$

3 Orzalesi N, Sorcinelli R, Binaghi F. Glucose-6-phosphate dehydrogenase in cataracts of subjects suffering from favism. Ophthalmic Res 1976; 8: 192-4.

4 Panich V, Na-Nakorn S. Glucose-6-phosphate dehydrogenase deficiency in senile cataracts. Hum Genet 1980; 55: 123-4.

5 Chen Y, Zeng L, Ma Q, Su W, Mao W. The study of glucose-6-phosphate dehydrogenase in erythrocyte and lens in mixed and premixed cataract. Eye Sci 1992; 8: $12-5$.

6 Zinkham WH. A deficiency of glucose-6-phosphate dehydrogenase activity in lens from individuals with primaquine-sensitive erythrocytes. Bull fohns Hopkins primaquine-sensitive eryt

7 Dovrat A, Gershon D. Rat lens superoxide dismutase and glucose-6-phosphate dehydrogenase: studies on the catalytic activity and the fate of enzyme antigen as a function of age. Exp Eye Res 1981; 33: 651-61.

8 Sparrow JM, Bron AJ, Brown NAP, Ayliffe N, Hill AR. The Oxford clinical cataract classification and grading system. Int Ophthalmol 1986; 9: 201-5.

9 Zinkham WH. Enzyme studies on lenses from persons with primaquine sensitive erythrocytes. Am $\mathcal{F}$ Dis Child 1960; 100: $525-6$.

10 Orzalesi N, Gorcinelli R, Guiso G. Increased incidence of cataracts in male subjects deficient in glucose-6-phos-

11 Angra SK, Munjal A, Jaffery NF. Glucose-6-P dehydrogenase and dermatoglyphics in congenital cataract. Proc 46th All India Ophthalmol Soc 1989: 174-80.

12 Vanella A, Sichle B, Celeris A. Superoxide dismutase activity and reduced glutathione content in cataractous lens of patients with glucose-6-phosphate dehydrogenase deficiency. Ophthalmol Paediatr Genet 1987; 8: 191-5. 